\title{
Front Matter: Volume 11238
}

, "Front Matter: Volume 11238," Proc. SPIE 11238, Optical Interactions with Tissue and Cells XXXI, 1123801 (4 March 2020); doi: 10.1117/12.2569811

SPIE. Event: SPIE BiOS, 2020, San Francisco, California, United States 


\section{Optical Interactions with Tissue and Cells XXXI}

Bennett L. Ibey

Norbert Linz

Editors

1-2 February 2020

San Francisco, California, United States

Sponsored and Published by

SPIE 
The papers in this volume were part of the technical conference cited on the cover and title page. Papers were selected and subject to review by the editors and conference program committee. Some conference presentations may not be available for publication. Additional papers and presentation recordings may be available online in the SPIE Digital Library at SPIEDigitalLibrary.org.

The papers reflect the work and thoughts of the authors and are published herein as submitted. The publisher is not responsible for the validity of the information or for any outcomes resulting from reliance thereon.

Please use the following format to cite material from these proceedings:

Author(s), "Title of Paper," in Optical Interactions with Tissue and Cells XXXI, edited by Bennett $\mathrm{L}$. Ibey, Norbert Linz, Proceedings of SPIE Vol. 11238 (SPIE, Bellingham, WA, 2020) Seven-digit Article CID Number.

ISSN: 1605-7422

ISSN: 2410-9045 (electronic)

ISBN: 9781510632394

ISBN: 9781510632400 (electronic)

Published by

SPIE

P.O. Box 10, Bellingham, Washington 98227-0010 USA

Telephone +1 3606763290 (Pacific Time) · Fax +1 3606471445

SPIE.org

Copyright (c) 2020, Society of Photo-Optical Instrumentation Engineers.

Copying of material in this book for internal or personal use, or for the internal or personal use of specific clients, beyond the fair use provisions granted by the U.S. Copyright Law is authorized by SPIE subject to payment of copying fees. The Transactional Reporting Service base fee for this volume is $\$ 21.00$ per article (or portion thereof), which should be paid directly to the Copyright Clearance Center (CCC), 222 Rosewood Drive, Danvers, MA 01923. Payment may also be made electronically through CCC Online at copyright.com. Other copying for republication, resale, advertising or promotion, or any form of systematic or multiple reproduction of any material in this book is prohibited except with permission in writing from the publisher. The CCC fee code is $1605-$ $7422 / 20 / \$ 21.00$.

Printed in the United States of America by Curran Associates, Inc., under license from SPIE.

Publication of record for individual papers is online in the SPIE Digital Library.

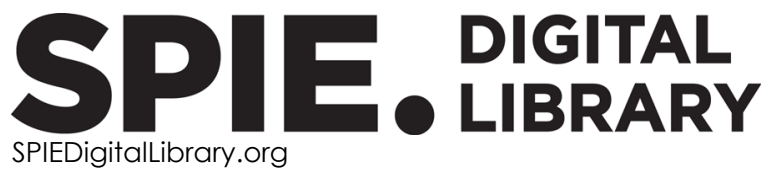

Paper Numbering: Proceedings of SPIE follow an e-First publication model. A unique citation identifier (CID) number is assigned to each article at the time of publication. Utilization of CIDs allows articles to be fully citable as soon as they are published online, and connects the same identifier to all online and print versions of the publication. SPIE uses a seven-digit CID article numbering system structured as follows:

- The first five digits correspond to the SPIE volume number.

- The last two digits indicate publication order within the volume using a Base 36 numbering system employing both numerals and letters. These two-number sets start with $00,01,02,03,04$, 05, 06, 07, 08, 09, OA, OB ... 0Z, followed by 10-1Z, 20-2Z, etc. The CID Number appears on each page of the manuscript. 


\section{Contents}

$\begin{array}{ll}\text { vii } & \text { Authors } \\ \text { ix } & \text { Conference Committee }\end{array}$

NOVEL APPLICATIONS OF LASERS AND LIGHT IN BIOMEDICINE

1123804 Characterisation of a Bessel beam optical cell sorting system using microspheres [11238-3]

NUMERICAL APPROACHES SIMULATING LASER-TISSUE INTERACTIONS AND RESPONSE

1123806 Optical radiation propagation based on Green's functions in biological skin tissues for enhanced coherence contrast [11238-5]

1123808 Retinal image analysis for eye safety evaluations of products emitting optical radiation [11238-7]

$1123809 \quad$ Neural network generation for estimation of tissue optical properties [1 1238-8]

11238 OA Modeling of a photoplethysmographic (PPG) waveform through Monte Carlo as a method of deriving blood pressure in individuals with obesity [1 1238-9]

PHOTOTHERMAL INTERACTIONS

11238 OC Porcine skin damage thresholds for multiple-pulse laser exposure at $1940 \mathrm{~nm}$ [11238-11]

11238 OD Multiple-pulse damage thresholds of retinal explants using top hat profiles [11238-12]

$11238 \mathrm{OE} \quad$ Human cadaver retina model for retinal heating during $\mathrm{OCT}$ assisted femtosecond laser cataract surgery [11238-13]

\section{MECHANISMS OF PULSED LASER ABLATION}

$112380 \mathrm{G}$ Characterization of photoablation versus incidence angle in soft tissue laser surgery: an experimental phantom study [11238-15]

$11238 \mathrm{OH} \quad$ Multi-fiber distributed temperature profiling in ex vivo magnetite nanoparticle-mediated laser tissue ablation [11238-16] 
OPTICAL PROPERTIES OF TISSUES I

11238 ON Compressed hyperspectral Raman microscope for imaging tissues and cellular structures [11238-22]

OPTICAL PROPERTIES OF TISSUES II

11238 OS Characterizing long lived intralipid-infused tissue phantoms scattering using imaging sensors [11238-27]

11238 OT Phase functions with large domain size for improved estimation of optical properties from subdiffusive reflectance [11238-28]

ULTRAFAST PULSED LASER INTERACTIONS

11238 OU Visualizing retinal hemorrhage thresholds for Q-switched Nd:YAG lasers in a novel porcine model [11238-29]

\section{CELLULAR BIOMOLECULAR RESPONSE}

$112380 Z$ Infrared laser-induced fast thermal gradient affects the excitability of primary hippocampal neurons [11238-34]

\section{POSTER SESSION}

1123811 Double-integrating-sphere system to measure the optical properties of turbid samples [11238-36]

$1123812 \quad$ Numerical and experimental study of the influence of device pressure on PPG signal acquisition [11238-37]

1123813 Laser biospeckle metrology in investigating plant-sound interactions [11238-38]

1123814 Monte-Carlo based simulations of photothermal response of nerve tissue for laser wavelengths of $1455 \mathrm{~nm}, 1490 \mathrm{~nm}, 1550 \mathrm{~nm}$ [11238-39]

1123815 Ultrahigh accurate statistical interferometric technique utilizing uniformity of speckle phase in the study of plant physiology [11238-40]

1123816 A pilot study: infrared laser stimulation of the rat vagus nerves [11238-41]

1123819 Tissue temperature monitoring during laser vaporization through black body radiation at wavelengths less than 1.8 um [11238-44] 
11238 1B Quantification and influence of skin chromophores for remote detection of anemic conditions [1 1238-46]

11238 1C Photochemical decomposition of uric acid crystals by ultra-short laser pulses [11238-47]

$112381 \mathrm{E} \quad$ Effect of microtubule resonant frequencies on neuronal cells [1 1238-49]

$1123811 \quad$ Salted cadaver brain measurement for light attenuation of PDT [11238-53] 
Proc. of SPIE Vol. 11238 1123801-6

\section{Downloaded From: https://www.spiedigitallibrary.org/conference-proceedings-of-spie on 26 Apr 2023
Terms of Use: https://www.spiedigitallibrary.org/terms-of-use}




\section{Authors}

Numbers in the index correspond to the last two digits of the seven-digit citation identifier (CID) article numbering system used in Proceedings of SPIE. The first five digits reflect the volume number. Base 36 numbering is employed for the last two digits and indicates the order of articles within the volume. Numbers start with 00, 01, 02, 03, 04, 05, 06, 07, 08, 09, OA, OB...0Z, followed by 10-1Z, 20-2Z, etc.

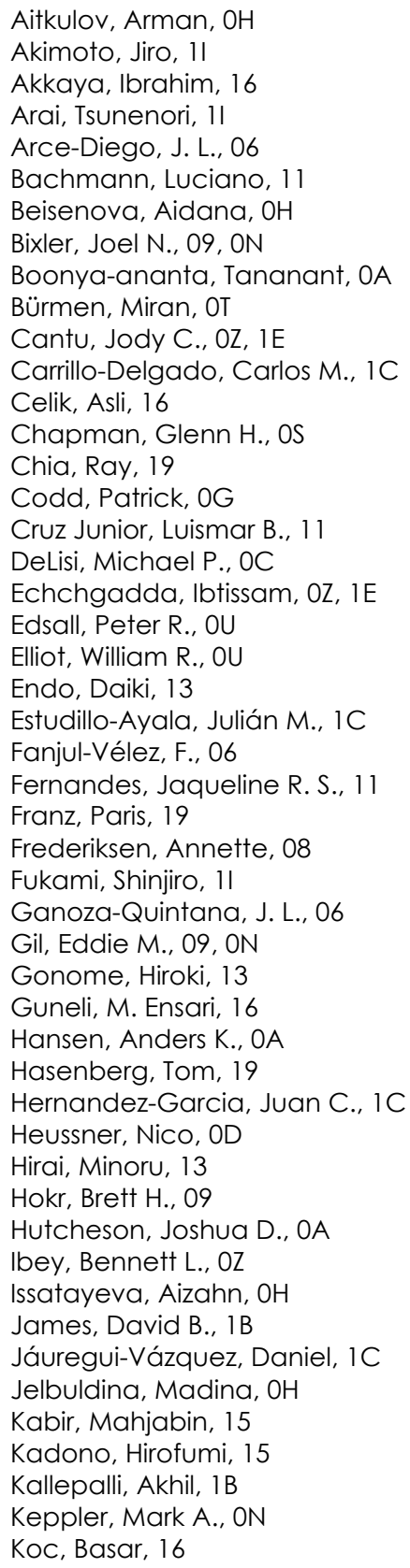

Kono, Takahiro, 13

Korganbayev, Sanzhar, $\mathrm{OH}$

Koshen, Dana, $\mathrm{OH}$

Kotzur, Sebastian, 08

Kulmukhanova, Nazerke, $\mathrm{OH}$

Kumagai, Hiroshi, 11

Kumru, Semih S., OC

Likar, Boštjan, OT

Liu, Zhiwen, 12

Lugongolo, Masixole Yvonne, 04

Lund, Brian, OU

Ma, Guangshen, 0G

Manoto, Sello, 04

Molardi, Carlo, $\mathrm{OH}$

Mthunzi-Kufa, Patience, 04

Naglič, Peter, OT

Noojin, Gary D., OC, ON, OU

O'Connor, Sean P., ON

Ogawa, Emiyu, 11

Ombinda-Lemboumba, Saturnin, 04

Paulsen, Sean, OS

Peralta, Xomalin G., 1E

Pernuš, Franjo, OT

Rafati, Yousef, 1E

Rajagopalan, Uma Maheswari, 13, 15

Ramella-Roman, Jessica C., OA

Ramos, Scarlett, OD

Rockwell, Benjamin A., OC, OU

Rodriguez, Andres J., OA

Rodriguez-Silva, Bryan A., 1C

Rojas-Laguna, Roberto, $1 \mathrm{C}$

Ross, Weston, OG

Schmidt, Morgan S., OC, OU

Schuster, Kurt J., OC, OU

Sedelnikova, Anna V., OZ, $1 E$

Sheng, Di, 12

Shingledecker, Aurora D., OC, OU

Sierra-Hernández, Juan M., $1 C$

Stork, Wilhelm, OD

Sui, Zhixuan, OE, OW

Sun, Hui, OE, OW

Tijerina, Amanda J., OC, OU

Tolstykh, Gleb P., OZ, 1E

Tosi, Daniele, $\mathrm{OH}$

Tozburun, Serhat, 14, 16

Tucker, Matthew, OG

Türker Burhan, Merve, 14

Valdez, Christopher M., 0Z, 1E

Wahl, Siegfried, 08 
Wang, Heuy-Ching $\mathrm{H}$., OU

Wang, Hui, 19

Wang, Qun, 12

Wang, Xiaomei, 19

Yakovlev, Vladislav V., ON

Yamada, Jun, 13

Yetis, Ozan, 16

Zelinskyi, Yevhen, OT

Zhang, Yutian, OS

Zhou, Zhiguo, 12

Zhu, Hui, 19

Proc. of SPIE Vol. 11238 1123801-8

Downloaded From: https://www.spiedigitallibrary.org/conference-proceedings-of-spie on 26 Apr 2023 Terms of Use: https://www.spiedigitallibrary.org/terms-of-use 


\section{Conference Committee}

Symposium Chairs

Jennifer K. Barton, The University of Arizona (United States)

Wolfgang Drexler, Medizinische Universität Wien (Austria)

Program Track Chairs

E. Duco Jansen, Vanderbilt University (United States)

Jessica C. Ramella-Roman, Florida International University

(United States)

Conference Chairs

Bennett L. Ibey, Air Force Research Laboratory (United States)

Norbert Linz, Universität zu Lübeck (Germany)

Conference Program Committee

Joel N. Bixler, Air Force Research Laboratory (United States)

Randolph Glickman, The University of Texas Health Science Center at San Antonio (United States)

Steven L. Jacques, Oregon Health \& Science University (United States)

Beop-Min Kim, Korea University (Korea, Republic of)

Alexander J. Makowski, Prozess Technologie (United States)

Anouk L. Post, The Netherlands Cancer Institute (Netherlands)

Jessica C. Ramella-Roman, Florida International University (United States)

William P. Roach, Vanderbilt University (United States)

Marissa Nicole Rylander, Virginia Polytechnic Institute and State University (United States)

Zachary D. Taylor, University of California, Los Angeles (United States)

Session Chairs

1 Novel Applications of Lasers and Light in Biomedicine

Bennett L. Ibey, Air Force Research Laboratory (United States)

2 Numerical Approaches Simulating Laser-Tissue Interactions and Response

Norbert Linz, Universität zu Lübeck (Germany)

3 Photothermal Interactions

Anouk L. Post, The Netherlands Cancer Institute (Netherlands) 
4 Mechanisms of Pulsed Laser Ablation

Alexander J. Makowski, Sciton, Inc. (United States)

5 Optical Monitoring of Tissue Mechanics

Alexander J. Makowski, Sciton, Inc. (United States)

6 Optical Properties of Tissues I

Bennett L. Ibey, Air Force Research Laboratory (United States)

7 Optical Properties of Tissues II

Joel N. Bixler, Air Force Research Laboratory (United States)

$8 \quad$ Ultrafast pulsed laser interactions

William P. Roach, Air Force Office of Scientific Research (United States)

9 Cellular Biomolecular Response

Bennett L. Ibey, Air Force Research Laboratory (United States) 